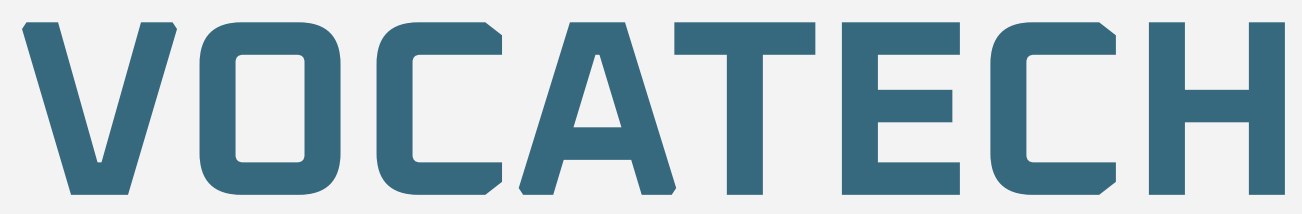

VOCATIONAL EDUCATION AND TECHNOLGY JOURNAL

Biannual

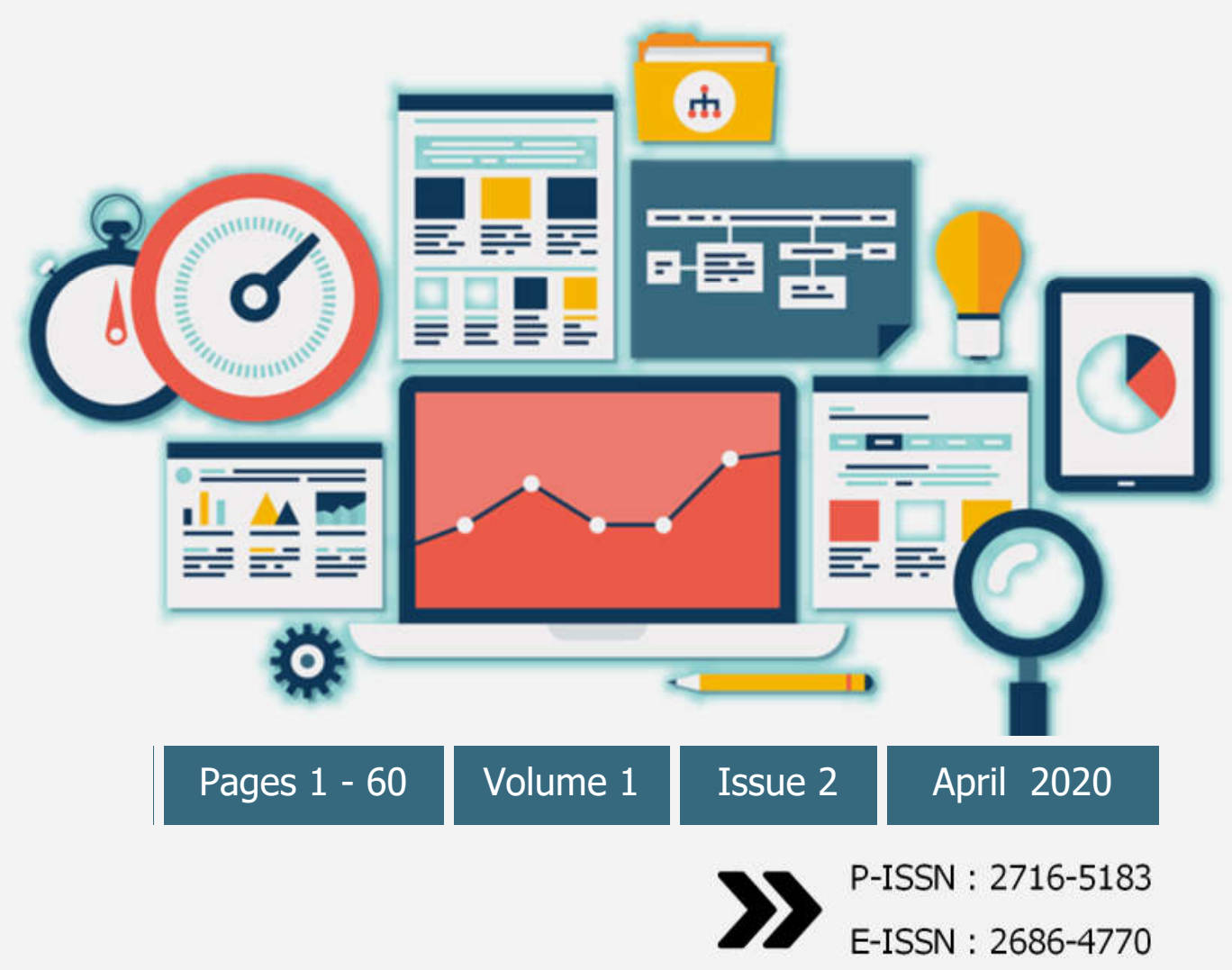

Published By: Unit Penelitian, Pengabdian Masyarakat dan Penjaminan Mutu Akademi Komunitas Negeri Aceh Barat

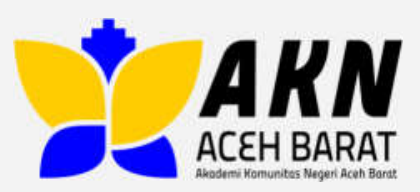




\section{P-ISSN : 2716-5183 \\ E-ISSN : 2686-4770

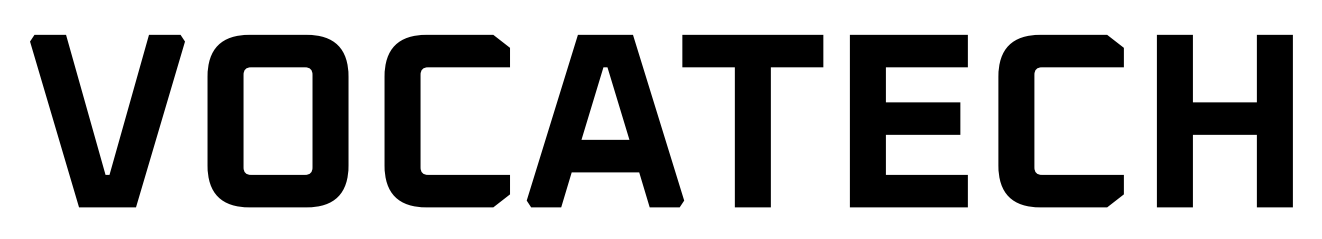

VOCATIONAL EDUCATION AND TECHNOLGY JOURNAL

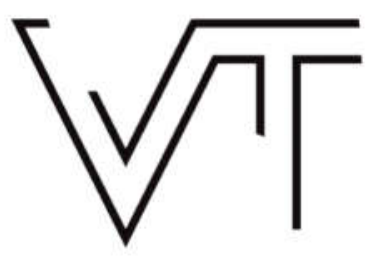

\section{Editorial Team}

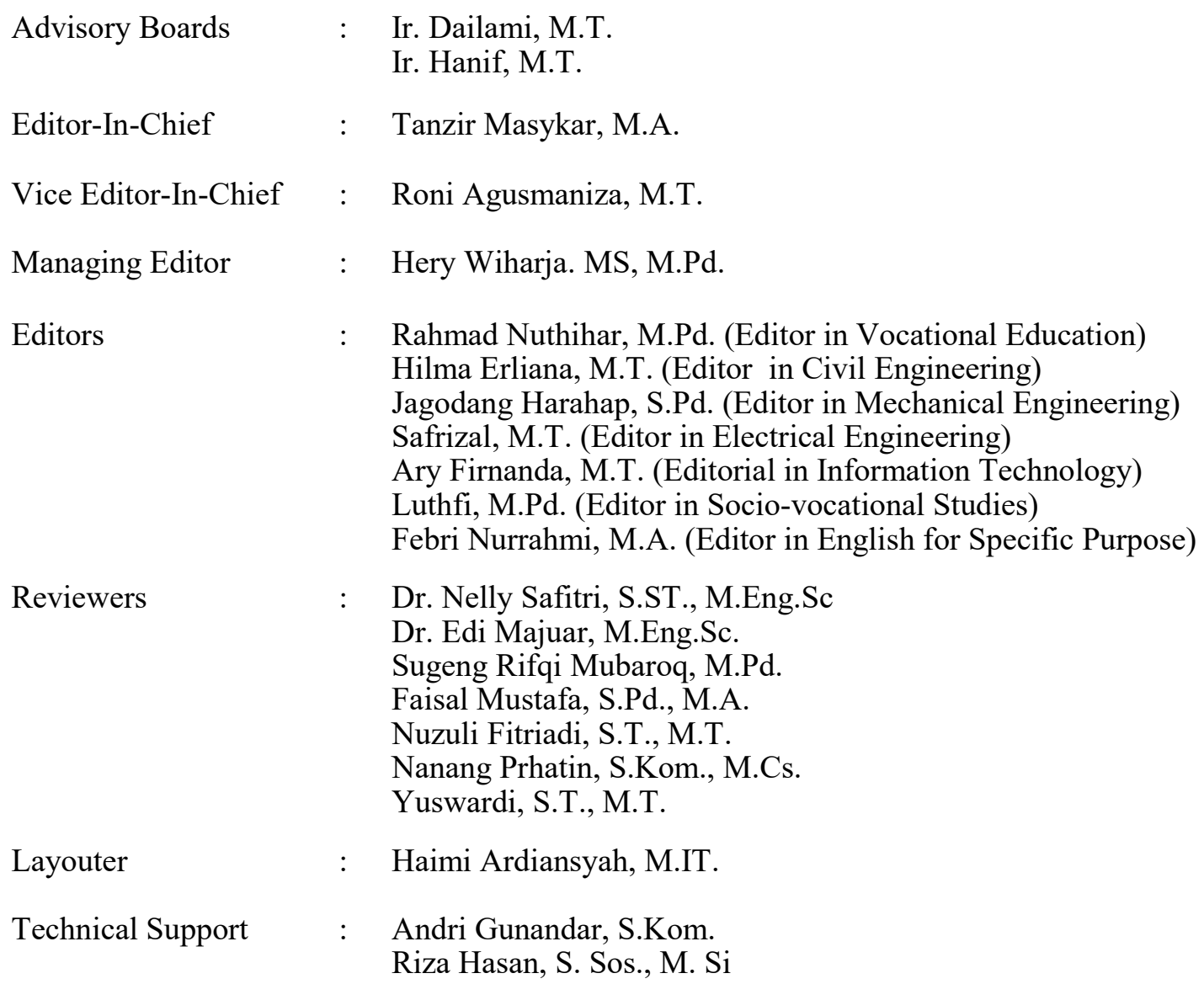

\section{Alamat Redaksi (Journal Address)}

Unit Penelitian, Pengabdian Masyarakat dan Penjaminan Mutu

Akademi Komunitas Negeri Aceh Barat

Komplek STTU Alue Peunyareng, Ujong Tanoh Darat, Meureubo, Kabupaten Aceh Barat, Aceh 23615, Indonesia

Website: http://ojs.aknacehbarat.ac.id/index.php/vocatech/index

Email:vocatech@akanacehbarat.ac.id 


\section{(2) \\ E-ISSN : 2686-4770

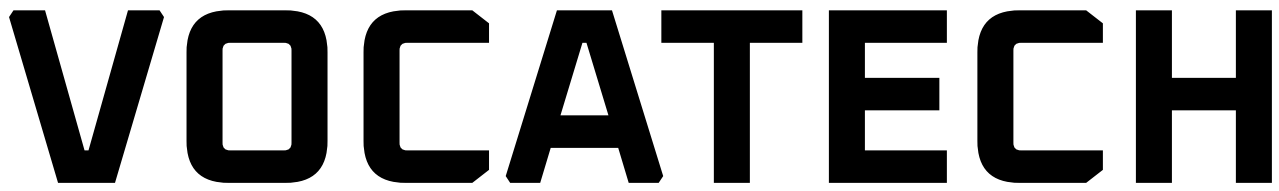 \\ VOCATIONAL EDUCATION AND TECHNOLGY JOURNAL}

\section{DAFTAR ISI (TABLE OF CONTENT)}

Pengaruh $R O E, D E R$, dan EPS Terhadap Harga Saham pada Emiten Syariah Sektor Barang

Konsumsi di BEI

—Dwi Meilvinasvita, Safaruddin, Yuliana—-

Penerapan General English dan English For Specific Purposes di Perguruan Tinggi Khususnya pada Pendidikan Vokasi

\section{—Rena Juliana, Reni Juliani-}

Pengaruh Penggunaan Kapasitor Bank pada Penyulang Kota di Pt. PLN (Persero) Rayon

Meulaboh Kota

-Haimi Ardiansyah-

Desain Alat Uji Impak Jatuh Bebas untuk Pengujian Baja Struktur

—Dailami, Hamdami, Samsul Bahri-

Analisis Kinerja Angkutan Kota dalam Provinsi di Provinsi Aceh Berdasarkan Pendekatan Load

Factor

—Ruhdi Faisal, Cut Mutiawati , Alfi Salmannur-

Klasifikasi Kematangan Buah Tomat dengan Variasi Model Warna Menggunakan Support Vector

Machine

\section{-Nica Astrianda-}

Implementasi Algoritma K-Mean dalam Pengelompokan Data Kecelakaan di Kabupaten Kediri

—Adimas Ketut Nalendra, M. Mujiono, Rafika Akhsani, Adiguna Sasama Wahyu U.- 


\title{
PENERAPAN GENERAL ENGLISH DAN ENGLISH FOR SPECIFIC PURPOSES DI PERGURUAN TINGGI KHUSUSNYA PADA PENDIDIKAN VOKASI
}

\author{
Rena Juliana* \\ Sekolah Tinggi Agama Islam Negeri Teungku Dirundeng, Meulaboh, Aceh \\ Reni Juliani \\ Universitas Teuku Umar, Meulaboh, Aceh
}

\begin{abstract}
The increasing role of English in this era of globalization seems to force us to recognize that English has a great impact on all aspects of life, so learning the English language is a must. Previously, studying English at Indonesian universities was limited to General English or English General Purposes, which became general subjects. However, over time, learning English has been developed specifically for English for Specific Purposes. This study is intended to show how the use of English learning at universities, especially in vocational education, works. In this study, the literature study was chosen as the research method. The literature study shows that the use of General English and English for Specific Purposes in higher education is very different. Where there is no special learning material for teaching General English. The learning material usually contains general knowledge of English. Unlike English for Specific Purposes, where teaching English for Specific Purposes requires special materials that are tailored to the needs of students depending on the subject.
\end{abstract}

Keywords:

Use, General English, English for Specific Purposes, University, Vocational Education.

\begin{abstract}
Abstrak
Meningkatnya peran bahasa Inggris di era globalisasi ini seolah memaksa kita untuk mengakui bahwa bahasa Inggris mempunyai pengaruh besar di segala aspek kehidupan sehingga mempelajari bahasa Inggris merupakan hal yang wajib. Sebelumnya di Indonesia, pembelajaran bahasa Inggris di perguruan tinggi hanya sebatas General English atau English for General Purposes yang menjadi mata kuliah umum, namun seiring berjalannya waktu pembelajaran bahasa Inggris dikembangkan lagi secara khusus dalam mata kuliah English for Specific Purposes. Studi ini memiliki tujuan untuk melihat bagaimana penerapan kedua pembelajaran bahasa Inggris tersebut di perguruan tinggi khususnya pada pendidikan vokasi. Studi pustaka dipilih sebagai metode penelitian dalam studi ini. Dari studi kepustakaan tersebut diperoleh hasil bahwa penerapan General English dan English for Specific Purposes di perguruan tinggi sangatlah berbeda antara keduanya. Dimana tidak ada materi pembelajaran khusus terhadap pengajaran General English. Materi pembelajaran biasanya berisikan pengetahuan umum tentang bahasa Inggris. Beda halnya dengan English for Specific Purposes, dimana dalam pengajaran English for Specific Purpose, dibutuhkan materi khusus yang disesuaikan dengan kebutuhan dari mahasiswa sesuai dengan bidang yang mereka ambil.
\end{abstract}

Kata Kunci:

Penerapan, General English, English for Specific Purposes, Perguruan Tinggi, Pendidikan Vokasi.

Received: 21 March, 2020 ; Revised: 28 March, 2020 ; Accepted: 31 March, 2020

DOI: https://doi.org/10.38038/vocatech.v1i2.26

\section{*Corresponding author:}

Rena Juliana, Program Studi Tadris Bahasa Inggris, Sekolah Tinggi Agama Islam Negeri Teungku Dirundeng Meulaboh, Jalan Lingkar Kampus, Gampong Gunong Kleng, Alue Penyareng,Kec. Meureubo, Aceh, Indonesia. Email: renajuliana@staindirundeng.ac.id

Citation in APA Style: Juliana, R., \& Juliani, R. (2020). Penerapan General English dan English for Specific Purposes di Perguruan Tinggi Khususnya pada Pendidikan Vokasi. VOCATECH: Vocational Education and Technology Journal, Vol. 1 (2), 14-20. 


\section{PENDAHULUAN}

Di era globalisasi ini, kemampuan bahasa asing khususnya bahasa Inggris yang menjadi bahasa internasional sangatlah diutamakan. Penyebaran penggunaan bahasa Inggris pun kini semakin meningkat dan berkembang pesat. Bukan hanya di kalangan negara-negara maju saja, negara-negara berkembang pun seperti Indonesia seakan tidak bisa lepas dari ketergantungan dalam penggunaan bahasa Inggris. Peran bahasa Inggris yang semakin dominan seolah memaksa mereka mengakui bahwa bahasa Inggris memang mempunyai pengaruh besar di segala aspek kehidupan saat ini.

Mengusung gerakan revolusi industri 4.0 bahkan akan menjelang revolusi industri 5.0. Indonesia harus mempersiapkan diri untuk menghadapi perkembangan teknologi informasi dan komunikasi yang semakin maju. Seperti yang dijelaskan oleh Roza (2013) bahwa bahasa pengantar yang digunakan pada berbagai informasi yang tersedia tentang ilmu pengetahuan dan teknologi dunia sebagian besar menggunakan bahasa Inggris. Selanjutnya Roza menambahkan bahwa komunikasi global sangat mengandalkan kemampuan bahasa Inggris dikarenakan untuk mengakses informasi yang disampaikan melalui berbagai media, baik media cetak maupun elektronik, bahasa inggris menjadi bahasa yang banyak dipakai (2013).

Dunia lapangan kerja juga semakin bersaing. Pelamar yang memiliki kemampuan bahasa asing yang baik akan menjadi pertimbangan dan menjadi poin plus dalam penilaian. Bukan hal yang baru lagi apabila penguasaan bahasa Inggris menjadi sebuah tuntutan baik secara lisan maupun tulisan. Oleh karena itu, pengajaran bahasa Inggris dirasa sangat penting sebagai bahasa asing pertama yang diajarkan di sekolah, mulai dari tingkat sekolah dasar sampai ke level yang lebih tinggi yaitu perguruan tinggi.

Mengingat bahwa penguasaan bahasa asing terutama bahasa Inggris sangatlah penting di semua aspek kehidupan terlebih lagi dalam dunia pendidikan. Untuk itu, seharusnya perguruan tinggi saat ini sudah harus lebih memprioritaskan kemampuan berbahasa asing khususnya bahasa Inggris. Terlebih lagi untuk pendidikan vokasi yang bukan hanya memerlukan pengajaran bahasa Inggris (General English) sebagai mata kuliah umum saja, tapi juga pengajaran bahasa Inggris yang lebih dikhususkan sesuai bidangnya masingmasing yang sekarang lebih dikenal dengan Bahasa Inggris untuk Tujuan Khusus atau English for Specific Purposes sebagai mata kuliah institusi. Dimana mahasiswa lebih khusus mempelajari bahasa Inggris yang sesuai dengan bidang dan kebutuhan mereka masing-masing.

Adapun fungsi dan tujuan pengajaran bahasa Inggris di Indonesia terutama pada lembaga-lembaga pendidikan tingkat lanjut seperti tertuang dalam Keputusan Menteri Pendidikan dan Kebudayaan No. 096/1967 tanggal 12 Desember 1967, yaitu pengajaran bahasa Inggris memiliki fungsi sebagai alat untuk mempercepat pembangunan negara dan bangsa, membentuk persahabatan dengan bangsa-bangsa lain dan menjalankan foreign policy. Adapun tujuannya adalah working knowledge of English yaitu effective reading ability, ability to understand spoken English, wirting ability, speaking ability (Halim, 1980).

Pada tingkat perguruan tinggi, bahasa Inggris yang dipelajari oleh mahasiswa di perguruan tinggi khususnya pada pendidikan vokasi seharusnya merupakan pengetahuan bahasa Inggris yang memang dibutuhkan pada bidangbidang tertentu bukan sekedar pengetahuan umum saja. Fauzia (2013) menjelaskan peran penting bahasa Inggris dalam pendidikan vokasi itu sendiri, sebagaimana dilihat dari tiga aspek, yaitu 1) aspek lulusan, 2) aspek pengguna lulusana, 3) aspek kemajuan pendidikan bangsa dan negara. Fauzia merincikan bagaiman peran bahasa Inggri dilihat dari aspek lulusan yaitu para lulusan mempunyai wawasan secara global, mampu bersaing dan mempunyai kemampuan bahasa Inggris pastinya, dapat dilihat dari skor TOEFL atau tes bahasa inggris lain yang diperoleh para lulusan. Kemudian dari aspek pengguna lulusan (stakeholder), memperoleh sumber daya yang berkualitas sangatlah menguntungkan. Para lulusan yang mempunya kemampuan bahasa Inggris yang baik akan mampu mengembangkan industri ke arah yang lebih luas, baik secara nasional maupun internasional, ketika melakukan kerjasama dengan pihak luar negeri, bahasa tidak lagi menjadi sebuah kendala. Masykar and Nurrahmi (2020) menemukan bahwa motivasi kebanyakan mahasiswa yang masuk pendidikan vokasi karena vokasi lebih fokus pada mengajarkan skill daripada toeri. Bahasa inggris praktis dibandingkan teoritis akan sangat 
dibutuhkan oleh mahasiswa vokasi. Aspek yang terakhir yaitu aspek kemajuan pendidikan bangsa dan negara yaitu adanya kemajuan dan proses pendidikan yang berkualitas sehingga pendidikan vokasi ini tidak lagi dipandang sebelah mata. Pendidikan vokasi akan menjadi terdepan karena menghasilkan lulusan yang bukan hanya memiliki kesiapan dan bakat dalam bidangnya, tetapi juga mampu bersaing secara global (Fauzia, 2013).

Melihat pentingnya peran bahasa Inggris untuk mahasiswa di perguruan tinggi khususnya pada pendidikan vokasi, Bahasa Inggris untuk Tujuan Khusus atau English for Specific Purposes dianggap sangatlah dibutuhkan. Oleh karena itu, studi ini memiliki tujuan untuk melihat bagaimana penerapan kedua pembelajaran bahasa Inggris tersebut di perguruan tinggi khususnya pada pendidikan vokasi, apakah terdapat perbedaan antara keduanya atau memiliki kesamaan dalam proses belajar mengajar.

\section{STUDI PUSTAKA}

\section{A. General English}

General English biasa dikenal sebagai mata kuliah Bahasa Inggris dan berisikan materi bahasa Inggris secara umum. Dalam struktur kurikulum perguruan tinggi, pada awalnya, mata kuliah Bahasa Inggris hanya termasuk ke dalam kelompok mata kuliah dasar umum (MKDU) dengan bobot 2 SKS (Kusni, 2007).

(Kitkauskienè, 2006, p. 89) menjelaskan bahwa "General English covers the teaching of the fundamentals of grammar, of expression as well as of phonetics and provides a stronger or weaker basis for possible later language studies". General English membahas tentang dasar dari bahasa Inggris itu sendiri, baik memperlajari aspek tata bahasa, pengucapan dan bunyi dan sebagai pondasi berbahasa yang baik dan benar. Dia juga menambahkan bahwa "In any case the language teacher both at a secondary and at a higher school is in charge of the correct use of the language by its learners" (Kitkauskienè, 2006). Merupakan tanggung jawab seorang guru atau pengajar baik di tingkat dasar, menengah, lanjut atau perguruan tinggi, untuk memperbaiki penggunaan bahasa Inggris siswanya.

Silabus yang digunakan untuk pengajaran mata kuliah Bahasa Inggris masih difokuskan pada pengajaran bahasa Inggris secara umum atau bisa dikatakan masih menggunakan pendekatan General English (GE). Pada perguruan tinggi, mata kuliah Bahasa Inggris atau General English di setiap program studi menggunakan silabus yang sama, sehingga materi yang diajarkan pun seragam, tidak khusus, dan tidak berorientasi pada bidang kajian masing-masing bidang pada program studi. Sedangkan kesesuaian silabus dengan bidang atau jurusan mahasiswa merupakan salah satu faktor penentu yang dapat mempengaruhi keberhasilan atau kegagalan pembelajaran itu sendiri [1]. Hal tersebut bisa dikatakan menjadi dasar lahirnya mata kuliah Bahasa Inggris untuk Tujuan Khusus atau lebih dikenal dengan sebutan English for Specific Purposes.

\section{B. $E S P$}

English for Specific Purposes atau sering disingkat dengan ESP merupakan salah satu bidang linguistik terapan yang sudah dikenal dan telah berkembang cukup lama bahkan dimulai dari awal tahun 1970-an. Sejalan dengan perkembangannya, di Indonesia sendiri istilah ESP juga sudah tidak asing lagi, namun istilah tersebut masih terbatas dan hanya familiar di kalangan akademisi tertentu yang berkecimpung dalam bidang pengajaran bahasa Inggris saja (Kusni, 2007).

(Robinson, 1991, p. 5) turut mendefinisikan ESP yaitu "It is generally used to refer to the teaching and learning of a foreign language for a clearly utilitarian purpose of which there is no doubt" (Robinson, 1991). Dengan demikian bisa dikatakan bahwa ESP ini merupakan pengajaran dan pembelajaran bahasa asing khususnya bahasa Inggris yang pendekatan dan asumsinya berbeda dengan General English.

(Nur, 2018, p. 88) menjelaskan bahwa ESP dalam hal ini lebih condong kepada pembelajaran bahasa dalam konteks daripada masalah kaidah bahasa (grammar) dan struktur bahasa itu sendiri. Oleh karena itu, konteks autentik dan penggunaan bahasa dalam situasi yang khas yang dikaitkan dengan bidang-bidang tertentu dapat membangkitkan semangat pembelajaran ESP (Nur, 2018).

Pada perguruan tinggi khususnya pada pendidikan vokasi, (Rusmala, 2018, p. 215) menjelaskan bahwa peran mata kuliah bahasa Inggris (General English), terlebih lagi ESP sangatlah besar terutama ketika mahasiswa sedang belajar ataupun saat mengunakan berbagai media, alat, atau mesin yang bahasa pengantarnya menggunakan bahasa inggris dan yang lebih penting lagi adalah ketika nantinya mahasiswa lulus dan mulai memasuki dunia kerja. Biasanya 
kualifikasi industri internasional membutuhkan sumber daya manusia yang mempunyai kemampuan bahasa asing (Rusmala, 2018).

Pada Gambar di bawah ini yang merupakan the Tree of ELT atau pohon cabang ilmu dari English Language Teaching (ELT) atau pembelajaran bahasa Inggris, Hutchinson dan (Hutchinson \& Waters, 2010) secara garis besar membagi ESP menjadi dua yaitu EAP (English for Academic Purposes) dan EOP (English for Occupational Purposes) (Hutchinson \& Waters, 2010).

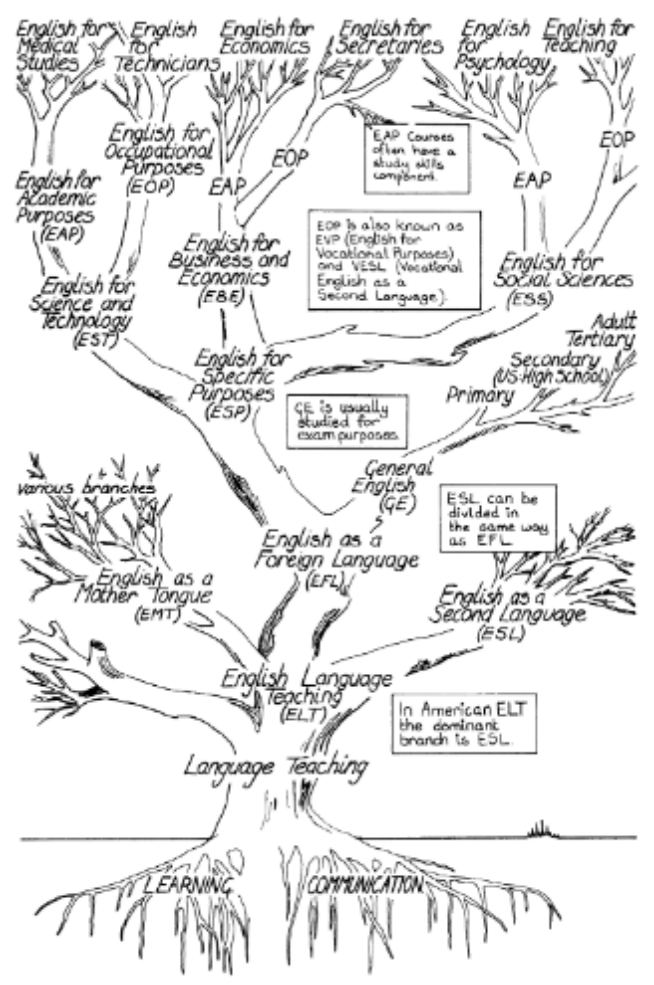

Gambar 1. The tree of ELT (Hutchinson \& Waters, 2010)

Hutchinson and Waters (2010) juga menjelaskan maksud dari pembagian itu sendiri seperti yang ada di Gambar 1 bahwa jika tujuan EAP adalah pembelajaran bahasa Inggris untuk tujuan dan kebutuhan akademis, maka EOP adalah pembelajaran bahasa Inggris untuk tujuan atau kebutuhan pekerjaan dan training (Hutchinson \& Waters, 2010).

Gambar selanjutnya di bawah ini merupakan klasifikasi ESP berdasarkan area profesional di mana (Dudley-Evans, St John, \& Saint John, 1998, p. 6) lebih terperinci menjabarkan tentang pembagian ESP tersebut. Senada dengan Hutchinson and Waters (2010), Dudley-Evans et al. (1998) membagi ESP menjadi dua bagian yaitu
EAP dan EOP. EAP terbagi kepada empat bagian yaitu English for Science Technology, English for Medical Purposes, English for Legal Purposes dan English for Management, Finance and Economics. EAP ini sendiri hanya berfokus pada bidang akademik saja. Fokus pada akademik di bidang teknologi sains, kedokteran, hukum, dan manajemen, keuangan dan ekonomi (Dudley-

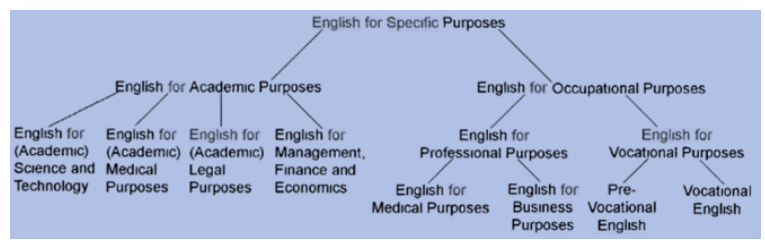

Evans et al., 1998).

Gambar 2. ESP classification by professional area (Dudley-Evans et al., 1998)

Dudley-Evans et al. (1998, p. 6) juga membagi EOP menjadi dua bagian yang terbagi lagi yaitu English for Professional Purposes yang terbagi menjadi English for Medical Purposes dan English for Business Purposes. Kemudian English for Vocational Purposes terbagi menjadi PreVocational English dan Vocational English. EOP ini sendiri berfokus pada pekerjaan yaitu bagaimana penggunaan bahasa Inggris atau kebutuhan bahasa Inggris di bidang pekerjaan profesional seperti kedokteran dan bisnis. Pada English for Vocational Purposes, yaitu PreVocational English fokus pada bagaimana mempersiapkan diri untuk mendapatkan sebuah pekerjaan dan mengasah skil wawancara. Sedangkan Vocational English lebih terfokus pada pelatihan-pelatihan untuk perdagangan atau pekerjaan yang lebih spesifik (Dudley-Evans et al., 1998).

\section{METODE}

Tulisan ini merupakan hasil sintesis dari kajian pustaka yang membahas bidang kajian pendidikan bahasa Inggris yang terfokus kepada penerapan General English dan English for Specific Purposes di perguruan tinggi khususnya pada pendidikan vokasi. Kajian pustaka yang dipergunakan dalam tulisan ini adalah beberapa buku dan jurnal lokal dan internasional baik bereputasi maupun tidak bereputasi yang diperoleh melalui penelusuran laman web Google Scholar dan Google Book.

Definisi kajian pustaka yang dipergunakan dalam tulisan ini adalah kajian pustaka yang 
dikemukakan oleh Maryati and Suryawati (2006, p. 129) yang menyatakan bahwa "studi kepustakaan adalah suatu kegiatan pengumpulan data dan informasi dari berbagai sumber, seperti buku yang memuat berbagai ragam kajian teori yang sangat dibutuhkan peneliti, majalah, naskah, kisah sejarah, dan dokumen" (Maryati \& Suryawati, 2006).

Melalui kajian analisis yang detail dan mendalam, rumusan tentang penerapan General English dan English for Specific Purposes di perguruan tinggi khususnya pada pendidikan vokasi dapat terformulasikan secara ilmiah.

\section{HASIL DAN PEMBAHASAN}

\section{A. Penerapan General English dan English for Specific Purposes di Perguruan Tinggi Khususnya pada Pendidikan Vokasi}

Membahas mengenai General English $(G E)$, Sofandi menjelaskan bahwa $G E$ sebenarnya mengacu pada pembelajaran bahasa Inggris yang general dan memiliki tujuan yang umum. Di dalam $G E$, dosen dan mahasiswa tidak mempunyai tujuan yang khusus dalam pembelajaran bahasa inggris tersebut. Henry menambahkan bahwa tujuan pembelajaran $G E$ ini mengarah pada peningkatan skill mahasiswa dalam mendengar, berbicara, membaca dan menulis dalam bahasa Inggris secara umum. Hal ini berbeda dengan tujuan pembelajaran bahasa Inggris pada English for Specific Purposes (ESP), ESP mempunyai tujuan pada pembelajaran bahasa Inggris yang bersifat khusus dalam bidang-bidang tertentu sehingga skill bahasa Inggris yang perlu ditingkatkan oleh mahasiswa harus sesuai dengan kebutuhan dan bidang studi mereka (Masykar, 2019).

Robinson turut menjelaskan tentang penerapan ESP bagi mahasiswa di perguruan tinggi yaitu pertama, mahasiswa mempelajari bahasa Inggris bukan berdasarkan rasa suka mereka terhadap bahasa Inggris atau kebudayaan bahasa Inggris tetapi dikarenakan mereka membutuhkan kemampuan berbahasa inggris guna mempelajari studi tertentu atau tujuan pekerjaan dengan topik-topik dan aktivitas yang berkaitan. Kedua, ESP dipelajari dengan landasan analisis kebutuhan. Poin utama dalam analisis kebutuhan ESP adalah terletak pada target apa yang dibutuhkan untuk kebutuhan pembelajaran. Ketiga, mahasiswa yang mempelajari ESP merupakan mereka yang sebelumnya telah belajar bahasa Inggris General English beberapa tahun dengan kata lain, mereka bukanlah pemula dalam belajar bahasa Inggris. Keempat, ESP bisa juga terdiri atas mahasiswa yang identik dimana mereka yang berada dalam kelas berasal dari jenis pekerjaan atau spesialis studi yang sama (Pontoh, Munaiseche, \& Pua, 2017).

\section{B. Materi Pembelajaran General English dan English for Specific Purposes}

General English yang diajarkan pada perguruan tinggi khususnya pada pendidikan vokasi sebagai mata kuliah umum untuk mahasiswa dengan latar belakang pendidikan yang beragam dan tidak termasuk dalam kerangka ESP dan sudah pasti tidak dapat dipakai pada pendidikan vokasi. Hal inilah yang menjadi pembeda antara ESP dan General English. Holme menyebutkan bahwa karakteristik silabus pendidikan bahasa itu ialah bersifat selektif dan berasal dari hasil analisa kebutuhan. Apalagi silabus General English membutuhkan kesesuaian dengan apa yang menjadi kebutuhan peserta didik. $\mathrm{Hal}$ ini yang mendasari kegiatan yang dipilih oleh pengajar untuk diajarkan dalam kelasnya nanti. Kegiatan pemilahan yang nantinya dijadikan sebagai materi pembelajaran adalah sebuah langkah awal dalam setiap pembuatan silabus pendidikan. Maka terlahirlah ESP dari proses kegiatan pemilihan ini dalam bentuk yang lebih spesifik sesuai dengan kebutuhan peserta didik (Masykar, 2019).

Mc Donough menyebutkan bahwa "ESP courses are those where the syllabus and materials are determined in all essentials by prior analysis of the communication needs of the learners." Hal ini menjelaskan bahwa bahan ajar dan silabus serta tujuan pembelajaran ESP mesti didesain dan dikembangkan sesuai dengan kebutuhan mahasiswa dan treasure study. Dengan kata lain, pendekatan ESP adalah pendekatan yang lininya bersifat vertikal yaitu dari bawah ke atas (Yaumi, 2017).

Robinson (1991, pp. 2-3) mengategorikan tiga karakteristik utama dari ESP yang membedakannya dengan General English. Ketiga ciri tersebut antara lain:

1. ESP merupakan pembelajaran yang fokus dan kiblatnya ada pada tujuan (goal oriented) pembelajaran itu sendiri. Hal ini dimaksudkan bahwa pembelajaran Bahasa Inggris tidak dilandaskan atas keingintahuan dari bahasa itu seperti rasa ingin tahu akan bahasa dan budaya yang ada di dalamnya, namun, pembelajaran bahasa Inggris pada ESP dilandaskan atas 
tujuan khusus, tertentu dan spesifik berdasarkan bidang kejuruan atau profesi yang dimiliki oleh peserta didik.

2. Esensi dari ESP didesain dan dikembangkan berlandaskan atas konsep analisis kebutuhan (need analysis). Pada konsep ini, materi pembelajaran akan disesuaikan dengan kebutuhan peserta didik yang berasal dari bidang tertentu. Konsep analisis kebutuhan memiliki tujuan untuk mengkhususkan materi bahasa Inggris kemudian mengkaitkannya dengan apa yang dibutuhakan peserta didik baik dalam bidang kejuruan maupun profesi.

3. ESP biasanya diajarkan pada level pendidikan menengah dan tinggi serta profesional atau juga diajarkan di tempat kerja. Hal ini yang melandasi ESP lebih ditujukan pada peserta didik dari kalangan dewasa dibandingkan dengan anak-anak ataupun remaja (Robinson, 1991).

Dari gambar di bawah ini, Jolly dan Bolitho mendeskripsikan petunjuk pengembangan materi pembelajaran yang bersifat dinamis. Hal ini menunjukkan bahwa model pengembangan bahan ajar di atas tentunya bisa dipergunakan tidak hanya dalam proses pembuatan materi pembelajaran namun juga dalam proses evaluasinya (Nurhidayati \& Kustini, 2018).

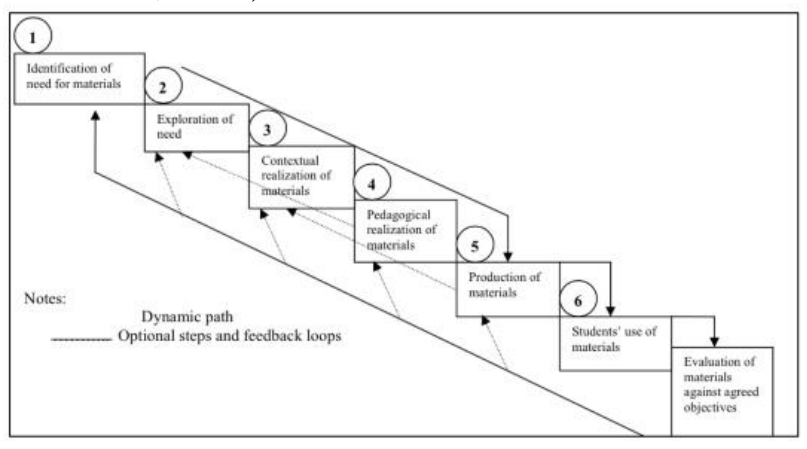

Gambar 3. Model Pengembangan Bahan Ajar

(Nurhidayati \& Kustini, 2018)

Dari Gambar 3 dapat dilihat bahwa ada enam step dalam pengembangan materi pembelajaran tersebut antara lain: identifikasi kebutuhan (identification of need for materials) dengan cara melakukan penyebaran angket pada peserta didik sehingga memperoleh feedback yang dapat mengidentifikasi kebutuhan mereka; eksplorasi kebutuhan (exploration of needs), setelah memperoleh feedback pembelajaran difokuskan pada unsur kebahasaan, fungsi, dan keterampilan yang disesuaikan dengan kebutuhan mereka; realisasi kontekstual (contextual realization of materials), pada tahapan ini, materi pembelajaran telah masuk ke pembahasan jenis teks, topik, dan tingkat kerumitan materi; realisasi pedagosik (pedagogical realization of materials), materi pembelajaran pada tahap ini yaitu dengan pemberian tugas dan instruksi belajar mengajar yang disesuaikan dengan peserta didik; produksi fisik (physical production) yang berisikan materi mengenai layout, tipe, ukuran, ilustrasi; dan evaluasi (evaluation of materials) setelah segala proses dilakukan, step terakhir yang akan ditempuh adalah pemberian saran dan feedback kepada peserta didik yang akan menjadi evaluasi dari materi pembelajaran tersebut (Nurhidayati \& Kustini, 2018).

Mengembangkan materi pembelajaran ESP bisa dikatakan merupakan proses yang cukup rumit dan membutuhkan pemikiran secara merinci dan mendalam. Secara teoritis, mengembangkan materi pembelajaran harus berlandaskan teori bahasa, teori pembelajaran bahasa, dan teori pendidikan juga dengan filosofinya. Materi pembelajaran yang dikembangkan merupakan pengembangan materi yang menyatukan keterampilan 4Cs yaitu communication, collaboration, creativity, dan critical thinking dengan tujuan untuk memberikan informasi dan saran bagi dosen ESP dalam mendesain dan mengembangkan materi pembelajaran yang menggabungkan teori pengembangan materi pembelajaran di bidang bahasa Inggris dengan keterampilan abad 21; menyuguhkan mahasiswa dengan bahan ajar yang inovatif dan terbaru yang disesuaikan dengan perkembangan zaman; selain itu juga membagikan ilmu, keahlian dan pengalaman untuk mahasiswa sehingga mereka bisa memperoleh informasi terbaru dengan kegiatan pembelajaran yang atraktif, menantang dan juga dengan tugas berdasarkan dengan level kemampuan bahasa Inggris mereka (Nurhidayati \& Kustini, 2018).

\section{KESIMPULAN}

Penerapan General English dan English for Specific Purposes di perguruan tinggi khususnya pada pendidikan vokasi sangatlah berbeda antar keduanya. Dimana tidak ada materi pembelajaran khusus terhadap pengajaran General English. Materi pembelajaran biasanya berisikan pengetahuan umum tentang bahasa Inggris. Beda halnya dengan English for Specific Purposes, dimana dalam pengajaran English for Specific 
Purposes, dibutuhkan materi khusus yang disesuaikan dengan kebutuhan dari mahasiswa sesuai dengan bidang yang mereka ambil. Mata kuliah English for Specific Purposes ini merupakan mata kuliah lanjutan setelah mahasiswa menyelesaikan mata kuliah General English.

\section{REFERENSI}

Dudley-Evans, T., St John, M. J., \& Saint John, M. J. (1998). Developments in English for specific purposes: A multidisciplinary approach: Cambridge university press.

Fauzia. (2013, December). Peran Pengajaran Bahasa Inggris dalam Pendidikan Vokasi. Paper presented at the Proc. Seminar Nasional Pendidikan Vokasi 2013: Pendidikan Vokasi sebagai Disiplin Keilmuan dalam Perspektif Kurikulum 2013.

Halim, A. (1980). Politik Bahasa Nasional 2. Jakarta: Balai Bahasa.

Hutchinson, T., \& Waters, A. (2010). English for Specific Purposes: A Learningcentred approach 25th. UK: Cambridge University Press.

Kitkauskienė, L. (2006). General English and English Forspecific Purposes (ESP). Santalka: Filologija, Edukologija, 14(2), 88-92.

Kusni. (2007). Reformulasi Perancangan Program ESP di Perguruan Tinggi. Linguistik Indonesia, 35(1), 63-72.

Maryati, K., \& Suryawati, J. (2006). Sosiologi untuk SMA dan MA Kelas XII. Jakarta: Erlangga.

Masykar, T. (2019). Analisa Kebutuhan English for Specific Purpose untuk Pendidikan Vokasi. VOCATECH: Vocational Education and Technology Journal, 1, 47-50.

Masykar, T., \& Nurrahmi, F. (2020). Motivation and satisfaction towards two-year vocational diploma. Jurnal Pendidikan Vokasi, 10(1).

Nur, M. (2018). Penerapan Esp Di Perguruan Tinggi Umum (Non English Majors)
Melalui Pendekatan Content-based Instruction-cbt. Mabasan, 12(1), 86103.

Nurhidayati, N., \& Kustini, S. (2018). Pengembangan Bahan Ajar Bahasa Inggris Berbasis Keterampilan Abad 21 pada Perguruan Tinggi Vokasi: Sebuah Kajian Literatur. Paper presented at the Proceeding of National Conference on Asbis.

Pontoh, G. H., Munaiseche, M. E., \& Pua, C. R. (2017). Pembelajaran Bahasa Inggris ESP untuk keterampilan Menulis. Paper presented at the Prosiding Industrial Research Workshop and National Seminar.

Robinson, P. C. (1991). ESP Today: Practitioner's Guide. New York: Prentice Hall.

Roza, M. (2013). Esp Dalam Pembelajaran Bahasa Inggris Di Ptai. Ijtimaiyya, 6(2), 143-156.

Rusmala, M. (2018, April). Peran Mata Kuliah Bahasa Inggris dalam Pendidikan Vokasi di STKOM Sapta Computer Kalsel. Paper presented at the Proc. Seminar Nasional Pendidikan: Peningkatan Kualitas Pendidikan Tinggi, Dasar dan Menengah.

Yaumi, M. (2017). Pengembangan bahan ajar English for specific purpose berbasis TIK. Lentera Pendidikan: Jurnal Ilmu Tarbiyah dan Keguruan, 15(2), 144160.

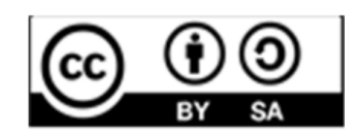

Copyright (C) 2020 Vocatech: Vocational Education and Technology Journal This works is licensed under a Creative Common Attribution-ShareAlike 4.0 